\title{
COMPARATIVE STUDY OF ANTIBACTERIAL ACTIVITY OF PLANT EXTRACTS FROM SEVERAL REGIONS OF ASIA
}

\author{
${ }^{1}$ Awatif Al-Judaibi, ${ }^{2}$ Ashwag Al-Zahrani, \\ ${ }^{3}$ Khadijah A. Altammar, ${ }^{4}$ Salmah Binti Ismail and ${ }^{4}$ Nadia T. Darweesh \\ ${ }^{1}$ Department of Biological Science, \\ ${ }^{2}$ Department of Food Science, \\ Faculty for Girls, King Abdulaziz University, Jeddah, Saudi Arabia \\ ${ }^{3}$ Department of Institute of Biological Science, Faculty of Science, \\ ${ }^{4}$ Department of Molecular Medicine, Faculty of Medicine, \\ University of Malaya, 50603, Kuala Lumpur, Malaysia
}

Received 2014-02-13; Revised 2014-02-25; Accepted 2014-04-02

\begin{abstract}
This study was designed to investigate the antibacterial activities of alcohol extracts of Phoenix dactylifera (date palm 'type Ajwa'), Nigella sativa (black cumin), Elettaria cardamomum (cardamom), Tinospora crispa (Akar patawali) and Panax ginseng (ginseng). The plant extracts were prepared with methanol and assayed for antibacterial activity against Methicillin-Resistant Staphylococcus Aureus (MRSA) and S. aureus. Extracts of $N$. sativa, E. cardamomum and $P$. ginseng produced maximum inhibition activities in the MRSA strain ATCC 33591, while $T$. crispa had the greatest activity in the strain ATCC 25923. The $P$. dactylifera extract had no effect on the tested bacteria. The growth inhibition was used to determine minimum inhibitory concentrations and minimum bactericidal concentrations. An in vivo experiment using the T. crispa ethanol extract in adult male and female Sprague Dawley rats $\left(4 \mathrm{~g} \mathrm{~kg}^{-1}\right.$ dose) showed low toxicity based on the $\mathrm{LD}_{50}$ value.
\end{abstract}

Keywords: Medicinal Plants, Methicillin-Resistant Staphylococcus Aureus, Antibacterial, Minimum Inhibitory Concentra-Tions

\section{INTRODUCTION}

The continent of Asia encompasses a variety of different topographies and types of soil. These differences are reflected in plant habitats as well as the composition of the plants themselves. The differences also appear in the many uses of native plants, some of which have medicinal properties. Some of the medicinal plants contain compounds that can cure infectious diseases through antibacterial, antifungal and antiviral activities (Andrade et al., 2011; Pereira and Gonzalez, 2004). Several studies have investigated antimicrobial agents found in medicinal plants that grow in Asia. Akhila et al. (2013) reported that water, ethanol, methanol and ethyl acetate extracts of Pajanelia longifolia had antibacterial activity against Staphylococcus aureus, Vibrio parahaemolyticus, Escherichia coli, Bacillus subtilis, Proteus mirabilis, Lactobacillus casei and L. fermentum. In addition, Pajanelia longifolia had significant levels of antimicrobial activity against V. parahaemolyticus and $B$. subtilis as well as antioxidant activity.

Methanol and ethanol extracts of Withania somnifera root showed antibacterial activity against B. subtilis, E. coli, Klebsiella pnuemoniae, Pseudomonas aeruginosa and Salmonella typhi, compared with commercially prepared gentamicin and tetracycline antibiotics discs (Jeyanthi et al., 2013). The study results also indicated that the ethanol and methanol extracts of W. somnifera root had effective antibacterial activity against the tested bacteria compared to antibiotic discs. Moreover, the methanol extract showed more activity than the ethanol extract. It was suggested that the bioactive compounds

Corresponding Author: Awatif Al-Judaibi, Department of Biological Science, Faculty for Girls, King Abdulaziz University, Jeddah, Saudi Arabia 
were responsible for the antibacterial activity; thus, the extract offered an alternative to antibiotics that is effective, safe, ecological and economical (Jeyanthi et al., 2013). In another study, methanol extracts of selected plants from northwestern Punjab were screened against $S$. aureus, E. coli and Pse. aeruginosa by Gul et al. (2012). Azadirachta indica and Mentha arvensis extracts had high antibacterial activity against Staphylococcus aureus, while extracts of Azadirachta indica, Cassia angustifolia, Phoenix dactylifera and Lawsonia inermis were effective against Candida albicans. Extracts of Diospyrosperegrina, Xylocarpus granatum, X. moluccensis and Pongamia pinnata and the essential oils of Citrus reticulata cv. Murcott (honey tangerine), showed antibacterial activity against Streptococcus equi, Bacillus cereus, Staphylococcus aureus, Enterobacter aerogenes, E. coli, Staphylococcus aureus, Shigella dysenteriae and Pse. aeruginosa (Ferhat et al., 2013; Wangensteen et al., 2013). Further, extracts and the essential oil of Nigella sativa have been reported to possess antimicrobial activity and $N$. sativa seeds with silver nanoparticles had antibacterial activity in the treatment of urinary tract infection (Hasan et al., 2013a; Ranjan et al., 2013).

In an investigation of the potential active compounds, Elettaria cardamomum was found to contain $8 \%$ volatile oils, comprising $0.2 \% \alpha$-phellandrene, $0.2 \% \beta$-pinene, $0.3 \%$ citronellol, $0.7 \% \quad \gamma$-terpinene, $1.5 \% \quad \alpha$-pinene, $1.6 \%$ myrcene, $2.7 \%$ trans-nerolidol and $2.8 \%$ sabinene; however, the volatile oil content in the seeds is dependent on storage conditions (Korikontimath et al., 1999). In another study, E. cardamomum yielded $2 \%$ to $8 \%$ essential oil, containing eucalyptol (cineole), sabinene, D- $\alpha$-terpineol, acetate and borneol; 1 to $2 \%$ of the fixed oil consisted of glycerides of oleic, stearic, linolenic, palmitic, caprylic and caproic acids (Keita et al., 2001; Tripathi et al., 2002; Balaji and Chempakam, 2008). Several studies investigated the antibacterial activity of Tinospora crispa, Eriobotrya japonica, Ficus carica and Phoenix dactylifera. Zakaria et al. (2006) found that T. crispa had antibacterial activity against pathogenic bacteria. Further, methanol extracts of fruits from E. japonica, F. carica and $P$. dactylifera showed higher antibacterial activity against E. coli, Pse. aeruginosa and $S$. aureus compared with chloroform extracts, which had reduced activity in all of these bacterial species (Mahmood et al., 2012).

Investigations can confirm that MRSA is acquired from the community rather than hospitals; the bacteria are identified and characterized by the presence and production of the virulence factor Panton-Valentine leukocidin. Unlike nosocomial MRSA infection, which is multidrug resistant, community-acquired MRSA does not have a multidrug-resistance mechanism; it can be treated with nonmethicillin antibacterial drugs (Munckhof et al., 2004). However, community-acquired MRSA can adapt and develop resistance as easily as nosocomial MRSA and infections with such bacteria were reported in children and young healthy adults in France (Francis et al., 2005).

A study on dithiocarbamates as novel organotin compounds, the compounds have been screened for antibacterial activity against $S$. aureus, S. typhimurium, $P$. aeruginosa and $B$. subtilis. The results of the study showed that one of these compound is promising aganit against $S$. aureus and S. typhi. On other hand, cytotoxicity results on human leukemic promyelocyte HL-60 cells showed an active of two of these compounds with $\mathrm{CD}_{50}$ values (Awang et al., 2011).

In this study, we compare the antibacterial activity of plants grown in Asia. Specifically, we investigate extracts of Phoenix dactylifera, Nigella sativa, Elettaria cardamomum, Tinospora crispa and Panax ginseng with regard to activity against MRSA. We also assess the activity of these extracts against strains of $S$. aureus isolated from two sources: One strain from King Abdulaziz University Hospital in Jeddah and three strains from the microbiology labor-atory of the University Malaya Medical Centre.

\section{MATERIALS AND METHODS}

\subsection{Study Bacteria}

Tested bacteria included MRSA ATCC 33591 and ATCC 25923, S. aureus MRSA isolated from King Abdulaziz university hospital and three MRSA strains from the microbiology laboratory of the University Malaya Medical Centre (MRSA ST/0904-30, MRSA ST/0904-31 and MRSA ST/0904-32). Assay plates were prepared by inoculating $100 \mu \mathrm{L}^{-1}$ of each sample $(1 \times 105$ colony-forming units [cfu]) onto MuellerHinton agar (OXOID CM 337).

\subsection{Study Plants and Extract Preparation}

The plants were collected from different locations. Phoenix dactylifera was from Almadina Almo-nawara city (Saudi Arabia), Nigella sativa and Elettaria cardamomum were from Jeddah markets, Tinospora crispa came from Malaya and Panax ginseng was from China. Nigella sativa seeds, $P$. dactylifera and $E$. cardamomum fruits, $T$. crispa leaves and $P$. ginseng flowers were washed with distilled water several times, spread on plates and dried at $40^{\circ} \mathrm{C}$. After drying, the plant materials were ground and solubilized in methanol $(P$. dactylifera, $N$. sativa and E. cardamomum) or ethanol ( $T$. crispa and $P$. ginseng) at $50 \mathrm{~g} 100 \mathrm{~mL}^{-1}$. The mixtures were kept on a $120 \mathrm{rpm}$ shaker at $30^{\circ} \mathrm{C}$ for $24 \mathrm{~h}$ and were 
then filtered using Whatman No. 1 filter paper. The filtered solvent was dried under reduced pressure at $40^{\circ} \mathrm{C}$ and the resultant deposits were used as crude extracts (Vijayakumar et al., 2013).

\subsection{Antimicrobial Assays}

The antimicrobial activity of each crude plant extract was determined in vitro against the grampositive MRSA. The activity of each extract was measured by disc diffusion and broth dilution methods per the Clinical and Laboratory Standards Institute (CLSI) protocol (CLSI, 2007).

For the disc diffusion method, each extract was dissolved in dimethylsulfoxide at $3 \mu \mathrm{g} \mathrm{mL}^{-1}$ and filtered through a $0.22 \mu \mathrm{m}$ pore filter (Millipore, Billerica, MA). One hundred microliters of each filtered solution was placed on paper discs (1 mm diameter), which were then set on a pre-inoculated agar surface. Negative controls were prepared with each solvent. Plates were incubated at $37^{\circ} \mathrm{C}$ for $24 \mathrm{~h}$ and the inhibition zones of each disc were measured. All tests were performed in triplicate.

\subsection{Minimum Inhibitory Concentration}

The extracts that inhibited the growth of tested bacteria were tested to determine the Minimum Inhibitory Concentration (MIC) by using a brothmicrodilution method (Wiegand et al., 2008). The bacteria were cultured overnight on Mueller-Hinton agar and then suspended in $1 \mathrm{~mL}^{-1}$ of Mueller-Hinton broth (OXOID CM 405) to give a final concentration of $5 \times 10^{5}$ cfu $\mathrm{mL}^{-1}$. Each extract was serially diluted with MuellerHinton broth in a 96-well microplate and the plates were inoculated with the bacteria and incubated at $37^{\circ} \mathrm{C}$ for 16-20 h. After incubation, plates were evaluated for the visible presence or absence of microbial growth. MIC was determined as the lowest concentration of an extract for which there was no visible growth compared to the control (Lambert et al., 2001).

\subsection{Minimum Bactericidal Concentration}

Minimum Bactericidal Concentration (MBC) was determined for $P$. dactylifera, $N$. sativa, E. cardamomum and $P$. ginseng by inoculating $0.1 \mathrm{~mL}$ of broth from negative growth wells in the MIC assay onto sterile nutrient agar by using streak plates. The plates were incubated at $37^{\circ} \mathrm{C}$ for $24 \mathrm{~h}$. The concentration that showed no growth of the tested organisms was considered to be the MBC; the negative control was a plate with medium only (Hernandes et al., 2013; Joshua and Takudzwa, 2013; Madigan et al., 1997).

\subsection{Body Weight Analysis and Liver and Renal Function Analysis}

In this in vivo test we focused on the T. crispa extract as the lees one on toxicity were studied. In order to determine a safe dosage for the plant extract, we under-took a study of the acute toxicity. Thirty-six adult male and female Sprague Dawley rats (8-10 weeks old, 180-200 $\mathrm{g}$ and 18 males, 18 females) were obtained from the Animal House, Faculty of Medicine, University of Malaya, Kuala Lumpur (ethics approval number: PM 07/05/2008 MAA (a) (R)). Equal numbers of rats were assigned to one of three groups: Control (vehicle: 10\% Tween-20, $5 \mathrm{~mL}$ $\mathrm{kg}^{-1}$ ), or 2 or $4 \mathrm{~g} \mathrm{~kg}^{-1}$ of plant extract preparation. The animals were given tap water and a standard pellet diet ad libitum for a minimum of 5 days before the start of the treatment to allow them to accli-mate. The treatment period was 2 weeks based on OECD guidelines. The amount of the plant extract dosage given to each rat was initially calculated based on the animal's body weight (Douds, 1997). Prior to testing, all animals were fasted overnight and food was withheld for another 3 to $4 \mathrm{~h}$ after dosing. The acute oral toxicity study was carried out based on the OECD Guideline for Testing of OECD (2001).

Each rat's weight was recorded as suggested by OECD guidelines before the $T$. crispa extract was administered. The animals' weights were also checked on the day of termination to determine if body weight changed with treatment.

Just before termination, the animals were anesthetized with diethyl ether. Blood was drawn from the jugular vein of each rat and collected in separate BD Vacutainer® blood collection tubes with clot activator (Becton-Dickinson, Franklin Lakes, New Jersey). All samples were sent immediately to the Clinical Diagnostic Laboratory of the University Malaya Medical Centre for liver and renal function tests. Results from these tests were compared to the respective control groups for the following parameters: Total protein, albumin, globulin, Alanine Aminotransferase (ALT), Aspartate Aminotransferase (AST), Alkaline Phosphatase (AP), creatinine and urea levels.

The $\mathrm{LD}_{50}$ value was estimated as being equal to the dose that would cause $50 \%$ mortality. The value of $\mathrm{LD}_{50}$ was also estimated as greater than the administered dose if less than $50 \%$ mortality occurred and lower if mortality exceeded 50\% (Douds, 1997). 


\subsection{Statistical Analysis}

The results were analyzed by paired-samples t-test using the IBM SPSS 20 statistical software to compare the mean values of each treatment. The results are expressed as means \pm SE. Probability levels of less than 0.01 were considered highly significant.

\section{RESULTS}

As shown in Table 1, high inhibition of growth occurred in most bacteria after treatment with $N$. sativa, E. cardamomum, $T$. crispa and $P$. ginseng extracts. Extracts of $P$. ginseng, E. cardamomum and $N$. sativa were associated, respectively, with 560, 240 and 580\% inhibition of MRSA ATCC 33591; these extracts yielded 260, 200 and 300\% inhibition of $S$. aureus, respectively. Tinospora crispa extract was associated with 126\%, 170, 166 and $160 \%$ inhibition for MRSA ATCC 25923, MRSA ST/0904-30, MRSA ST/0904-31 and MRSA ST/0904-32, respectively. In contrast, the extract of the $P$. dactylifera fruit did not inhibit bacterial growth. Among extracts that were associated with bacterial growth inhibition, the methanol extracts were more effective than the ethanol extracts.

The inhibition of bacterial growth was reflected in the MIC of the plant extracts (Table 2). In the assays with MRSA ATCC 33591, the highest MICs were $1 \mu \mathrm{g} \mathrm{mL}^{-1}$ for $N$. sativa and E. cardamomum and $2 \mu \mathrm{g} \mathrm{mL}^{-1}$ for P. ginseng, while MRSA ATCC 25923 assays with $T$. crispa had an MIC of $32 \mu \mathrm{g} \mathrm{mL}^{-1}$. The MICs were 4,2 and $2 \mu \mathrm{g} \mathrm{mL} \mathrm{m}^{-1}$ with $P$. ginseng, $N$. sativa and $E$. cardamomum, respectively, in treatments for the isolated $S$. aureus. Further, T. crispa treatment yielded MICs of 32, 16 and $32 \mu \mathrm{g} \mathrm{mL}^{-1}$ in MRSA ST/0904-30, MRSA ST/0904-31 and MRSA ST/0904-32, respectively. The MBCs of the $N$. sativa, E. cardamomum and $P$. ginseng extracts are shown in Table 3. The highest MBCs were 1 $\mu \mathrm{g} \mathrm{mL}^{-1}$ with $N$. sativa and E. cardamomum and $8 \mu \mathrm{g}$ $\mathrm{mL}^{-1}$ with $P$. ginseng for MRSA ATCC 33591.

Table 4 shows changes in the animals' body weight after 14 days. No significant difference was observed in any of rat groups compared to their respective control groups. The liver function parameters that were tested included serum total protein, albumin, globulin, ALT, AST and AP (Table 5).

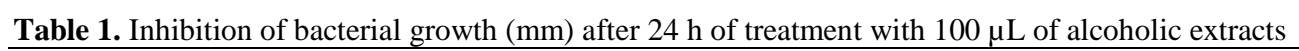

\begin{tabular}{llllll}
\hline & $\begin{array}{l}\text { Panax } \\
\text { ginseng }\end{array}$ & $\begin{array}{l}\text { Tinospora } \\
\text { crispa }\end{array}$ & $\begin{array}{l}\text { Elettaria } \\
\text { cardamomum }\end{array}$ & $\begin{array}{l}\text { Nigella } \\
\text { sativa }\end{array}$ & $\begin{array}{l}\text { Phoenix } \\
\text { dactylifera }\end{array}$ \\
\hline MRSA ATCC 335910 & $34 \pm 0.101^{* *}$ & $\mathrm{NT}$ & $17.0 \pm 0.076^{* *}$ & $34.0 \pm 0.076^{* *}$ & 0 \\
MRSA ATCC 25923 & $\mathrm{NT}$ & $11.3 \pm 0.110^{* *}$ & $\mathrm{NT}$ & $\mathrm{NT}$ & $\mathrm{NT}$ \\
S. aureus & $18 \pm 0.093^{* *}$ & $\mathrm{NT}$ & $15.0 \pm 0.109^{* *}$ & $20.0 \pm 0.076^{* *}$ & 0 \\
MRSA ST/0904-30 & $\mathrm{NT}$ & $13.5 \pm 0.160^{* *}$ & $\mathrm{NT}$ & $\mathrm{NT}$ & $\mathrm{NT}$ \\
MRSA ST/0904-31 & $\mathrm{NT}$ & $13.3 \pm 0.093^{* *}$ & $\mathrm{NT}$ & $\mathrm{NT}$ & NT \\
MRSA ST/0904-32 & $\mathrm{NT}$ & $13.0 \pm 0.174^{* *}$ & $\mathrm{NT}$ & $\mathrm{NT}$ & NT \\
\hline
\end{tabular}

NT: Not tested. $* * \mathrm{p}<0.01$

Table 2. MIC $(\mu \mathrm{g} / \mathrm{mL})$ of bacterial growth after $20 \mathrm{~h}$ of treatment with serial concentrations of alcoholic extracts

\begin{tabular}{|c|c|c|c|c|c|}
\hline & $\begin{array}{l}\text { Panax } \\
\text { ginseng }\end{array}$ & $\begin{array}{l}\text { Tinospora } \\
\text { crispa }\end{array}$ & $\begin{array}{l}\text { Elettaria } \\
\text { cardamomum }\end{array}$ & $\begin{array}{l}\text { Nigella } \\
\text { sativa }\end{array}$ & $\begin{array}{l}\text { Phoenix } \\
\text { dactylifera }\end{array}$ \\
\hline MRSA ATCC 33591 & 2 & NT & 1 & 1 & - \\
\hline MRSA ATCC 25923 & NT & 32 & NT & NT & NT \\
\hline S. aureus & 4 & NT & 2 & 2 & - \\
\hline MRSA ST/0904-30 & NT & 32 & NT & NT & NT \\
\hline MRSA ST/0904-31 & NT & 16 & NT & NT & NT \\
\hline MRSA ST/0904-32 & NT & 32 & NT & NT & NT \\
\hline
\end{tabular}

NT: Not tested

Table 3. MBC $(\mu \mathrm{g} / \mathrm{mL})$ of bacterial growth after $24 \mathrm{~h}$ of incubation in Mueller-Hinton agar

\begin{tabular}{|c|c|c|c|c|c|}
\hline & $\begin{array}{l}\text { Panax } \\
\text { ginseng }\end{array}$ & $\begin{array}{l}\text { Tinospora } \\
\text { crispa }\end{array}$ & $\begin{array}{l}\text { Elettaria } \\
\text { cardamomum }\end{array}$ & $\begin{array}{l}\text { Nigella } \\
\text { sativa }\end{array}$ & $\begin{array}{l}\text { Phoenix } \\
\text { dactylifera }\end{array}$ \\
\hline MRSA ATCC 33591 & 2 & NT & 1 & 1 & - \\
\hline MRSA ATCC 25923 & NT & NT & NT & NT & NT \\
\hline S. aureus & 8 & NT & 4 & 8 & - \\
\hline MRSA ST/0904-30 & NT & NT & NT & NT & NT \\
\hline MRSA ST/0904-31 & NT & NT & NT & NT & NT \\
\hline MRSA ST/0904-32 & NT & NT & NT & NT & NT \\
\hline
\end{tabular}

NT: Not tested 
Table 4. Body weights of rats treated with ethanol extracts of T. crispa

\begin{tabular}{lll}
\hline & Mean \pm SE & \\
Dose $(\mathrm{g} / \mathrm{kg})$ & $-\mathrm{-ody}$ weight $(\mathrm{g})$ day 0 & Body weight $(\mathrm{g})$ day 15 \\
\hline 4 & $192.33 \pm 3.06$ & $197.16 \pm 1.66$ \\
0 & $194.33 \pm 2.59$ & $197.33 \pm 2.66$ \\
0 (vehicle) & $199 \pm 0.70$ & $199.75 \pm 0.25$ \\
\hline
\end{tabular}

Table 5. Liver function analysis of rats in acute toxicity study of ethanol extract of T. crispa

\begin{tabular}{|c|c|c|c|c|c|c|}
\hline \multirow[b]{2}{*}{ Dose $(\mathrm{g} / \mathrm{kg})$} & \multicolumn{6}{|l|}{ Mean \pm SE } \\
\hline & $\mathrm{TP}(\mathrm{g} / \mathrm{L})$ & ALP (g/L) & GLB (g/L) & ALT (IU/L) & AST (IU/L) & AP (IU/L) \\
\hline 4 & $60.67 \pm 1.80$ & $12.00 \pm 0.51$ & $48.66 \pm 1.47$ & $70.50 \pm 6.86$ & $207.50 \pm 14.63$ & $164.66 \pm 21.11$ \\
\hline 2 & $61.00 \pm 1.12$ & $12.33 \pm 0.81$ & $48.66 \pm 0.98$ & $69.16 \pm 3.23$ & $209.66 \pm 7.25$ & $166.50 \pm 23.53$ \\
\hline 0 (vehicle) & $56.50 \pm 1.93$ & $10.75 \pm 0.62$ & $45.75 \pm 1.43$ & $59.00 \pm 2.08$ & $200.25 \pm 9.25$ & $121.75 \pm 11.77$ \\
\hline
\end{tabular}

Table 6. Renal function analysis of rats in acute toxicity study of ethanol extract of $T$. crispa extracts

\begin{tabular}{lll}
\hline & $($ Mean \pm SEM, $\mathrm{n}=6)$ & \\
& - & \\
Dose $(\mathrm{g} / \mathrm{kg})$ & Creatinine $(\mu \mathrm{mol} / \mathrm{L})$ & Urea $(\mathrm{mmol} / \mathrm{L})$ \\
\hline 4 & $51.00 \pm 2.16$ & $7.70 \pm 0.62$ \\
2 & $45.66 \pm 1.35$ & $7.10 \pm 0.40$ \\
0 (vehicle) & $50.25 \pm 2.42$ & $7.35 \pm 0.54$ \\
\hline
\end{tabular}

Creatinine and urea levels of all groups were determined as markers of kidney function (Table 6). No significant changes were found in any of the liver or kidney parameters tested in comparisons of the treatment and control groups. Additionally, there were no significant differences in any parameters between males and females in any group.

The results of this study may further strengthen the recommendation for the use of the tested plants in the treatment and control of microbial infections.

\section{DISSCUSION}

The growth inhibition analysis in our study showed varied activity of plant extracts, the plant and the solvent type.

Our results on methanol extracts agreed with those of Joshua and Takudzwa (2013) who extracted Mangifera indica stem bark using four different solvents (methanol, ethyl acetate, hexane and distilled water) and testing the antibacterial efficacy of the extracts against $S$. aureus. They found that the methanol extract was the most effective. Our results also agreed with a previous study (Al-Judaibi and Al-Yousef, 2013) using methanol extracts of Rhamnus globosa, Ocimum basilicum, Tecoma stans and Coleus forskohlii against grampositive cocci, including Staphylococcus aureus, $S$. epidermidis, S. saprophyticus, Streptococcus pyogenes and Str. agalactiae. The plant extracts inhibited bacterial growth and the highest inhibitory effect was achieved by treatment with $O$. basilicum in each of the five tested bacterial strains.

Screenings of the antimicrobial activity of extracts from plants, honey and black cumin oil were conducted in other studies, which showed that diethyl ether extracts were the most effective antimicrobial compounds and their activity was the most pronounced against grampositive bacteria (Nostro et al., 2000; Adam, 2013).

Several studies have been performed to determine the MICs and MBCs of medicinal plant extracts, includ-ing extracts of $P$. longifolia, Piper nigrum, Syzygium aromaticum, Pelargonium graveolens, Myristica fragrans, Origanum vulgare, Thymus vulgaris, Rosmarinus officinalis, Rumex alveolatus (leaves), Calophyllum Rubiginosum (stem bark) Capsella bursa, Mangifera indica, Moringa oleifera, Psidium guajava, Murraya koenigii, Ficus infectoria, Satureja bachtiarica, Aristolochia indica (leaf and flowers), Cassia angustifolia, Catharanthus roseus (leaf), Diospyros melanoxylon, Dolichos biflorus, Gymnema sylvestre, Justicia procumbens, Dissotis perkinsiae, Adenocarpus mannii and Barteria fistulosa. These studies used species of gram-negative and gram-positive bacteria and the MICs and MBCs were similar to those found in our study (Dorman and Deans, 2000; ALkhamaiseh et al., 2011; Kamaraj et al., 2012; Akhila et al., 2013; Choudhury et al., 2013; Hasan et al., 2013b; Sureshjani et al., 2013; Mohammadi-Sichani et al., 2013; Ndjateu et al., 2014).

The negative findings for $P$. dactylifera fruit extract may be due to the components being ineffective against the tested bacteria. According to Jamil et al. (2010), P. dactylifera contains inorganic elements, including $\mathrm{K}, \mathrm{Zn}$, 
$\mathrm{Ca}$ and traces of $\mathrm{Cr}$, that are required for cellular functions and may consequently support bacterial growth. The lack of activity may also be due to the solvent used and the type of bacteria. Saddiq and Bawazir (2010), for example, found that Klebsiella pneumonia and Escherichia coli growth was inhibited by treatment with $P$. dactylifera water extracts, with inhibition zones of 16.351 and $10.00 \mathrm{~mm}$, respectively. Further, an acetone extract of $P$. dactylifera was shown to be a potential antiviral agent against pathogenic human viruses (Jassim and Naji, 2007).

The high antimicrobial effect of the medicinal plant extracts may be due to secondary metabolites in the plant tissues and phytochemical studies have indicated that the plants' antimicrobial activities are associated with compounds such as flavonoids, terpenes, alkaloids, tannins, hydroxyl group and phenol and essential oils such as yarrow, carvacrol, thymol, glycosides, tannins, saponins and steroids (Dorman and Deans, 2000; Choudhury et al., 2013; Jadha et al., 2013; Joshua and Takudzwa, 2013).

The findings on phytochemical compounds is in accordance with the report of Zakaria et al. (2006), who found that an ethanol extract of $T$. crispa was bacteriostatic against $S$. aureus. When used at higher concentrations, ethanol has a stronger extraction capacity than other solvents, which could draw out several important antibacterial substances like tannins, saponins and alka-loids (Akinyemi et al., 2005; Abu-Shanab et al., 2006; Sule and Agbabiake, 2008); the current study's findings bear out this observation as well. Aside from the high volatility of ethanol, the nature of biological active com-pounds (i.e., tannins and alkaloids) may played a role in their being chemically more susceptible to ethanol extraction (Akinyemi et al., 2005).

According to Sudjana et al. (2009), the tested organisms Campylobacter jejuni, Helicobacter pylori and $S$. aureus including MRSA were inhibited by ethanol extracts, suggesting that the plant extract acted specifically against the gram-positive cell wall due to its effectiveness against all the staphylococcal strains. The reason may be due to the extracts' hydrophobicity, which caused cell rupture as a result of the destruction of the membrane's structure (Nitta et al., 2002).

Extract effects on body weight were insignificant in comparisons of treatment and control groups. Liver parameters, including serum total protein, albumin, globulin, ALT, AST and AP, were also evaluated. ALT and AST are considered good markers for liver function (Hilaly et al., 2004; Mehta et al., 2009) and high serum levels of these enzymes are indicative of damage to hepatic cells (Kumar et al., 2009). Decreased amounts of total protein, albumin and globulin in the serum suggest chronic liver damage; most plasma proteins are synthesized in the liver and their levels can be used to evaluate the synthesizing capacity of the liver (Rasekh et al., 2008; Mehta et al., 2009). A severe histological change in the liver can be indicated by a rise in the level of serum AP and secretion of large amounts into the plasma (Sharma et al., 2008). A significant increase in serum levels of renal enzymes is a conventional indicator of kidney damage or nephrotoxicity (Sharma et al., 2008), but no such increase was observed in our present study. Overall, the extracts did not appear to have significant effects on the liver and renal function parameters in any of the treated groups or between sexes based on comparisons to control groups. However, the period of exposure to the extract was only 2 weeks, leaving open the possibility that longer exposure could still be detrimental.

\section{CONCLUSION}

This study showed that alcohol extracts of Nigella sativa (black cumin), Elettaria cardamomum (cardamom), Tinospora crispa (Akar patawali) and Panax ginseng (ginseng) had antibacterial effects on $S$. aureus MRSA and growth inhibition was reflected in the MICs and MBCs. Further, the ethanol extract of $T$. crispa appeared to have low toxic effects, with an $\mathrm{LD}_{50}$ value that exceeded $4 \mathrm{~g} \mathrm{~kg}^{-1}$.

\section{ACKNOWLEDGEMENT}

The authors would like to acknowledge and thank the Government of the Kingdom of Saudi Arabia for providing the third author a master scholarship.

\section{REFERENCES}

Abu-Shanab, B., G. Adwan, N. Jarrar, A. Abu-Hijleh and K. Adwan, 2006. Antibacterial activity of four plant extracts used in palestine in folkloric medicine against methicillin-resistant staphylococcus aureus. Turkish J. Biol., 30: 195-198.

Adam, M.E., 2013. Antimicrobial activity of bee honey, black cumin oil and green tea against multi-drug resistant pathogenic bacteria. Int. J. Curr. Microbiol. Applied. Sci., 2: 58-63.

Akhila, Z., R. Bhat P.S. Acharya, A. Yende and S. Padyana, 2013. Studies on antioxidant and antimicrobial activities of pajanelia longifolia (Willd.) schumann. J. Res. Obesity. DOI: 10.5171/2013. 756484 
Akinyemi, K.O., O. Oladapo, C.E. Okwara, C.C. Ibe and K.A. Fasure, 2005. Screening of crude extracts of six medicinal plants used in South-West Nigerian unorthodox medicine for anti-methicillin resistant Staphylococcus aureus activity. BMC Complementary Alternative Med. DOI: 10.1186/1472-6882-5-6

ALkhamaiseh, S.I., M. Taher and F. Ahmad, 2011. The phytochemical contents and antimicrobial activities of Malaysian calophyllum rubiginosum. Am. J. Applied Sci., 8: 201-205. DOI: 10.3844/ajassp.2011.201.205

Al-Judaibi, A. and F. Al-Yousef, 2013. Effect of natural products from plant extracts on Gram-positive cocci. World Acad. Sci. Eng. Technol., 83: 315-319.

Andrade, M.A., M.G. Cardoso, L.R. Batista, J.M. Freire and D.L. Nelson, 2011. Antimicrobial activity and chemical composition of essential oil of Pelargonium odoratissimum. Brazilian J. Pharmacognosy, 21: 47-52. DOI: 10.1590/S0102695X2011005000009

Awang, N., I. Baba, B.M. Yamin, M.S. Othman and N.F. Kamaludin, 2011. Synthesis, characterization and biological activities of organotin (iv) methylcyclohexyldithiocarbamate compounds. Am. J. Applied Sci., 8: 310-317. DOI: 10.3844/ajassp.2011.310.317

Balaji, S. and B. Chempakam, 2008. Mutagenicity and carcinogenicity prediction of compounds from cardamom (Elettaria cardamom Maton). Ethnobotanical Leaflets, 12: 682-689.

Choudhury, S., L. Sharani and M.P. Sinha, 2013. Pharmacological efficacy of some medicinal plants used for treatment of gastrointestinal diseases. IQJES, 3: 111-116.

CLSI, 2007. Performance standards for antimicrobial susceptibility testing; Seventeenth information supplement. CLSI document M100-S17 (M2-A7 and M7-A7) 27(1). Clinical and laboratory Standards institute, Wayne, Pa.

Dorman, H.J.D. and S.G. Deans, 2000. Antimicrobial agents from plants: Antibacterial activity of plant volatile oils. J. Applied Microbiol., 88: 308-316. DOI: 10.1046/j.1365-2672.2000.00969.x

Douds, D.A., 1997. An acute oral toxcity study in rats with Advantra $Z^{\mathrm{TM}}$. Washington, Ave: Nu-traech, Inc.

Ferhat, M., Z. Khan, P. Shahzadi, T. Yaseen and T.A. Mughal et al., 2013. A comparative study of in vitro total antioxidant, in ivvo antidiabetic and antimicrobial activities of essential oils from leaves and rind of citrus reticulate blanco cv. Murcot (Honey). Pak. J. Bot., 45: 1571-1576.
Francis, J.S., M.C. Doherty, U. Lopatin, C.P. Johnston and G. Sinha et al., 2005. Severe community-onset pneumonia in healthy adults caused by methicillinresistant staphylococcus Aureus carrying the pantonvalentine leukocidin genes. Clin. Infect. Dis., 40: 100-107. PMID: 15614698

Gul, F., Z.K. Shinwari and I. Afzal, 2012. Screening of indigenous knowledge of herbal remedies for skin diseases among local communities of North West Punjab, Pakistan. Pak. J. Bot., 44: 1609-1616.

Hasan, A., M. Zaini and H.A. Malek, 2013a. Antimicrobial activity of nigella sativa seed extract (aktiviti antimikrob ekstrak nigella sativa). Sains Malaysiana, 42: 143-147.

Hasan, R.N., M.R. Ali, S.M. Shakier, A.M. Khudhair and M.S. Hussin et al., 2013b. Antibacterial activity of aqueous and alcoholic extracts of capsella bursa against selected pathogenic bacteria. Am. J. Bio. Sci., 1: 6-10. DOI: 10.11648/j.ajbio.20130101.12

Hernandes, C., J.D.S. Coppede, B.W. Bertoni, S.D.C. França and A.M.S. Pereira, 2013. Flash microbiocide: A rapid and economic method for determination of MBC and MFC. Am. J. Plant Sci., 4: 850-852. DOI: 10.4236/ajps.2013.44104

Hilaly, J.E., Z.H. Israili and B. Lyoussi, 2004. Acute and chronic toxicological studies of Ajuga iva in experimental animals. J. Ethnopharmacol., 91: 4350. DOI: 10.1016/j.jep.2003.11.009

Jadha, S., R. Shah, M. Bhave and E.A. Palombo, 2013. Inhibitory activity of yarrow essential oil on Listeria planktonic cells and biofilms. Food Control, 29: 125-130. DOI: 10.1016/j.foodcont.2012.05.071

Jamil, M.S., R. Nadeem, M.A. Hanif, M.A. Ali and K. Akhtar, 2010. Proximate composition and mineral profile of eight different unstudied date (Phoenix dactylifera L.) varieties from Pakistan. Afr. J. Biotechnol., 9: 3252-3259.

Jassim, S.A.A. and M.A. Naji, 2007. In vitro evaluation of the antiviral activity of an extract of date palm (phoenix dactylifera 1.) Pits on a Pseudomonas Phage. Adv. Access Public., 7: 57-62. DOI: 10.1093/ecam/nem160

Jeyanthi, T., P. Subramanian and P. Kumaravel, 2013. A comparative analysis of antibacterial activity of withania somnifera root extract with commercial antibiotics. Asian J. Pharm. Res., 3: 98-102.

Joshua, M. and M. Takudzwa, 2013. Antibacterial properties of mangifera indica on staphylococcus aureus. Afr. J. Clin. Experimental Microbiol., 14: 62-74. 
Kamaraj, C., A.A. Rahuman, C. Siva, M. Iyappan and A.V. Kirthi, 2012. Evaluation of antibacterial activity of selected medicinal plant extracts from south India against human pathogens. Asian Pacific J. Tropical Dis., 2: S296-S301. DOI: 10.1016/S2222-1808(12)60169-8

Keita, S.M., C. Vincent, J.P. Schmit, J.T. Arnason and A. Bélanger, 2001. Efficacy of essential oil of Ocimum basilicum L. and $O$. gratissimum L. applied as an insecticidal fumigant and powder to control Callosobruchus maculatus (Fab.) [Coleoptera: Bruchidae]. J. Stored Prod. Res., 37: 339-349. DOI: 10.1016/S0022-474X(00)00034-5

Korikontimath, V.S., R. Mulge and J.T. Zachariah, 1999. Variations in essential oil constituents in high yielding selections of cardamom. J. Plant. Craps, 27: 230-232.

Kumar, S.S., R.R. Kumar and G.K. Mohan, 2009. Hepatoprotective effect of Trichosanthes cucumerina Var cucumerina L. on carbon tetrachloride induced liver damage in rats. J. Ethnopharmacol., 123: 347-350. PMID: 19429383

Lambert, R.J.W., P.N. Skandamis, P.J. Coote and G.J.E. Nychas, 2001. A study of the minimum inhibitory concentration and mode of action of oregano essential oil, thymol and carvacrol. J. Applied Microbiol., 91: 453-462. PMID: 11556910

Madigan, M.T., J.M. Martinko and J. Parker, 1997. Brock Biology of Microorganisms. 8th Edn., Prentice Hall International, Inc. New York.

Mahmood, S., S. Bashir, K. Farzana, M.R. Akram and M.A. Abrar et al., 2012. Differential inhibition of common bacterial species by extracts of three fruits using different solvents. Philipp Agric. Sci., 95: 169174.

Mehta, A.K., N. Arora, S.N. Gaur and B.P. Singh, 2009. Acute toxicity assessment of choline by inhalation, intraperitoneal and oral routes in Balb/c mice. Regul. Toxicol. Pharmacol., 54: 282-286. PMID: 19460409

Mohammadi-Sichani, M., P. Sadeghzadeh and M. Madani, 2013. Evaluation of antibacterial activity of extract of rumex alveollatus leaf against staphylococcus aureus and pseudomonas aeruginosa. ZJRMS, 15: 58-61.

Munckhof, W.J., S.L. Kleinschmidt and J.D. Turnidge, 2004. Resistance development in communityacquired strains of methicillin-resistant Staphylococcus aureus: An in vitro study. Int. J. Antimicrobial. Agents, 24: 605-608. PMID: 15555885
Ndjateu, F.S.T., R.B.N. Tsafack, B.K. Nganou, M.D. Awouafack and H.K. Wabo et al., 2014. Antimicrobial and antioxidant activities of extracts and ten compounds from three Cameroonian medicinal plants: Dissotis perkinsiae (Melastomaceae), Adenocarpus mannii (Fabaceae) and Barteria fistulosa (Passifloraceae). South African J. Botany, 91: 37-42. DOI: 10.1016/j.sajb.2013.11.009

Nitta, T., T. Arai, H. Takamatsu, Y. Inatomi and T. Tanaka et al., 2002. Antibacterial activity of extract prepared from tropical and subtropical plants on methicillin-resistant staphylococcus aureus. J. Health Sci., 48: 273-276. DOI: 10.1248/jhs.48.273

Nostro, A., M.P.Á. Germano, V. D'Angelo, A. Marino and M.A. Cannatelli, 2000. Extraction methods and bioautography for evaluation of medicinal plant antimicrobial activity. Lett. Applied Microbiol., 30: 379-384. DOI: 10.1046/j.1472-765x.2000.00731.x

OECD, 2001. Guideline for testing of chemicals (420): Acute oral toxicity-fixed dose procedure. Adopted: 17th December 2001.

Pereira, J.C. and J. Gonzalez, 2004. Rumen degradability of dehydrated beet pulp and dehydrated citrus pulp. Anim. Res., 53: 99-110. DOI: 10.1051/animres:2004005

Ranjan, P., M.P. Das, M.S. Kumar, P. Anbarasi and S. Sindhu et al., 2013. Green synthesis and Characterization of Silver nanoparticles from Nigella sativa and its application against UTI causing Bacteria. J. Academia Industrial Res., 2: 45-49.

Rasekh, H.R., P. Nazari, M.K. Nejad and L. Hosseinzadeh, 2008. Acute and 54 subchronic oral toxicity of Galega officinalis in rats. J. Ethnopharmacol., 116: 21-26. DOI: $10.1016 /$ j.jep.2007.10.030

Saddiq, A.A. and A.E. Bawazir, 2010. Antimicrobial activity of date palm (phoenix dactylifera) pits extracts and its role in reducing the side effect of methyl prednisolone on some neuro-transmitter content in the brain, hormone testosterone in Adulthood. Acta Hort. (ISHS) 882: 665-690.

Sharma, S., R.P. Goyal, G. Chakravartya and A. Sharma, 2008. Toxicity of tomato red, a popular food dye blend on male albino mice. Experimental Toxicol. Pathol., 60: 51-57. DOI: 10.1016/j.etp.2007.11.005

Sudjana, A.N., C. D’Orazio, V. Ryan, N. Rasool and J. $\mathrm{Ng}$ et al., 2009. Antimicrobial activity of commercial Olea europaea (olive) leaf extract. Int. J. Antimicrobial. Agents, 33: 461-463. DOI: 10.1016/j.ijantimicag.2008.10.026 
Sule, I.O. and T.O. Agbabiaka, 2008. Antibacterial effect of some plant extracts on selected enterobacteriaceae. Ethnobotanical Leaflets, 12: 1035-1042.

Sureshjani, M.H., F.T. Yazdi, A. Mortazavi, F. Shahidi and B.A. Behbahani, 2013. Antimicrobial effect of Satureja bachtiarica extracts aqueous and ethanolic on Escherichia coli and Staphylococcus aureus. Scientific J. Biol. Sci., 2: 24-31.

Tripathi, A.K., V. Prajapati, N. Verma, J.R. Bhal and R.P. Bansal et al., 2002. Bioactivities of the leaf essential oil of Curcuma longa (Var. Ch-66) on three species of stored-product beetles (Coleoptera). J. Econ. Entomol., 95: 183-189. DOI: 10.1603/0022-0493-95.1.183

Vijayakumar, M., K. Priya, F.T. Nancy, A. Noorlidah and A.B.A. Ahmed, 2013. Biosynthesis, characteri-sation and anti-bacterial effect of plantmediated silver nanoparticles using Artemisia nilagirica. Indust. Crops Products, 41: 235-240. DOI: $10.1016 /$ j.indcrop.2012.04.017
Wangensteen, H., L. Klarpås, M. Alamgir, A.B.C. Samuelsen and K.E. Malterud, 2013. Can scientific evidence support using bangladeshi traditional medicinal plants in the treatment of diarrhoea? Rev. Seven Plants. Nutrients, 5: 17571800. DOI: $10.3390 /$ nu5051757

Wiegand, I., K. Hilpert and R.E.W. Hancock, 2008. Agar and broth dilution methods to determine the Minimal Inhibitory Concentration (MIC) of antimicrobial substances. Nature Protocols, 3: 163-175. DOI: $10.1038 /$ nprot.2007.521

Zakaria, Z.A., A.M.M. Jais, E.F. Henie, H. Zaiton and M.N. Somchit et al., 2006. The in vitro antibacterial activity of Tinosprora crispa Extracts. J. Biol. Sci., 6: 398-401. DOI: 10.3923/jbs.2006.398.401 